University of Nebraska - Lincoln

DigitalCommons@University of Nebraska - Lincoln

\title{
Changes in the timing of high river flows in New England over the 20th Century
}

G. A. Hodgkins

U.S. Geological Survey, gahodgki@usgs.gov

R. W. Dudley

U.S. Geological Survey

T. G. Huntington

U.S. Geological Survey

Follow this and additional works at: https://digitalcommons.unl.edu/usgsstaffpub

Part of the Earth Sciences Commons

Hodgkins, G. A.; Dudley, R. W.; and Huntington, T. G., "Changes in the timing of high river flows in New England over the 20th Century" (2003). USGS Staff -- Published Research. 423.

https://digitalcommons.unl.edu/usgsstaffpub/423

This Article is brought to you for free and open access by the US Geological Survey at DigitalCommons@University of Nebraska - Lincoln. It has been accepted for inclusion in USGS Staff -- Published Research by an authorized administrator of DigitalCommons@University of Nebraska - Lincoln. 


\title{
Changes in the timing of high river flows in New England over the 20th Century
}

\author{
G.A. Hodgkins* , R.W. Dudley, T.G. Huntington \\ US Geological Survey, 196 Whitten Road, Augusta, ME 04330, USA
}

Received 30 August 2002; accepted 14 April 2003

\begin{abstract}
The annual timing of river flows is a good indicator of climate-related changes, or lack of changes, for rivers with long-term data that drain unregulated basins with stable land use. Changes in the timing of annual winter/spring (January 1 to May 31) and fall (October 1 to December 31) center of volume dates were analyzed for 27 rural, unregulated river gaging stations in New England, USA with an average of 68 years of record. The center of volume date is the date by which half of the total volume of water for a given period of time flows past a river gaging station, and is a measure of the timing of the bulk of flow within the time period. Winter/spring center of volume (WSCV) dates have become significantly earlier $(p<0.1)$ at all 11 river gaging stations in areas of New England where snowmelt runoff has the most effect on spring river flows. Most of this change has occurred in the last 30 years with dates advancing by 1-2 weeks. WSCV dates were correlated with March through April air temperatures $(r=-0.72)$ and with January precipitation $(r=-0.37)$. Three of 16 river gaging stations in the remainder of New England had significantly earlier WSCV dates. Four out of 27 river gaging stations had significantly earlier fall center of volume dates in New England. Changes in the timing of winter/spring and fall peak flow dates were consistent with the changes in the respective center of volume dates, given the greater variability in the peak flow dates. Changes in the WSCV dates over the last 30 years are consistent with previous studies of New England last-frost dates, lilac bloom dates, lake ice-out dates, and spring air temperatures. This suggests that these New England spring geophysical and biological changes all were caused by a common mechanism, temperature increases.
\end{abstract}

Published by Elsevier Science B.V.

Keywords: Streamflow; Trend detection; Spring; Fall; Variability; Climate change

\section{Introduction}

The flow of a river represents the integrated basin response to various climatic inputs, with precipitation and temperature being very important. Changes over time in the hydrology of unregulated

\footnotetext{
* Corresponding author. Tel.: +207-622-8201x121; fax: + 207622-8204.

E-mail address: gahodgki@usgs.gov (G.A. Hodgkins).
}

basins with stable land use generally reflect changes in climatic conditions and can be used as indicators of climate change. In addition to providing an understanding of the effects of climate change on society and ecosystems, such analyses provide measures of climate change that are based on river flow data. The river flow instrumentation is independent of the instrumentation used for other climatic measures such as temperature (Zhang et al., 2001). 
Many researchers have shown the value of using historical river flows as climatic indicators. Various researchers have analyzed changes in river flows over time at national and international scales (Hyvarinen and Leppajarvi, 1989; Lettenmaier et al., 1994; Lins and Michaels, 1994; Chiew and McMahon, 1996; Lins and Slack, 1999; Dettinger and Diaz, 2000; Douglas et al., 2000; Zhang et al., 2001; Burn and Hag Elnur, 2002; McCabe and Wolock, 2002). National and regional studies have looked at seasonal changes over time in river flows by looking at the ratio of seasonal to annual flows (Aguado et al., 1992; Dettinger and Cayan, 1995), the magnitude of monthly flows (Lettenmaier et al., 1994; Zhang et al., 2001; Burn and Hag Elnur, 2002) or the timing of seasonal peak flows or a computed measure of the start of seasonal flow (Burn, 1994; Cayan et al., 2001; Zhang et al., 2001).

New England is an important region to study changes over time in the seasonal distribution of river flows. In addition to having many rural, unregulated rivers with more than 50 years of continuous flow data, it is a mid-latitude region with a large climatic gradient. The median total seasonal snowfall ranges from less than 40 in. in southern New England to more than 100 in. in northern New England (Cember and Wilks, 1993). The near-freezing temperatures present in the late fall, winter, and early spring make New England rivers sensitive to small changes in temperature. The relative amount of precipitation falling as rain or snow directly affects the timing of river flow in these seasons.

The largest river flows in New England typically are in the spring when rain falls on a ripe snowpack or on saturated soils. For example, at the Swift River in northern New England (Table 1, Fig. 1), 46\% of the total flow from 1930 to 2000 occurred in April and May. For the Yantic River in southern New England, 32\% of the flow from 1931 to 2000 occurred in March and April. The lower percentage of flow at the Yantic River corresponds with a lower and earlier spring snowmelt runoff. In the fall, after evapotranspiration decreases substantially, repeated rains often saturate the soil, leading to large flows. Also in the fall, large amounts of rain have fallen from hurricanes, tropical storms, or their remnants.

The objective of this study was to analyze the longterm temporal variation of river flow in these two high-flow seasons in New England because of their possible sensitivity to documented climate change in the last century. Annual temperatures and precipitation in New England have increased in the 20th century (Intergovernmental Panel on Climate Change, 2001). To accomplish this objective, we used the center of volume date, the date by which half of the total volume of water for a given period of time flows by a river gaging station; and the peak flow date, the highest daily mean flow within a season. The center of volume date is more sensitive to changes in the timing of flow than is the percentage of flow occurring in one or more fixed months (Court, 1962). The center of volume date is expected to be a more robust indicator of the timing of the bulk of high-flows in a season than the peak flow, since the peak flow can occur before or after the bulk of seasonal flows. We computed seasonal center of volume dates and peak flow dates for the winter/spring (January 1 to May 31) and fall (October 1 to December 31) seasons. In general, climatic warming would result in earlier winter/spring center of volume (WSCV) dates because of an increased ratio of winter rainfall to snowfall and because of earlier snowmelt runoff. Later fall center of volume dates could result from increased early fall evapotranspiration or an increased ratio of early winter rainfall to snowfall. Increased precipitation also could change the seasonal timing of flows in either season, depending on when the increased precipitation occurred.

\section{Methodology}

\subsection{Data}

The US Geological Survey (USGS) developed a list of river flow gaging stations that are relatively free of anthropogenic influences such as regulation, diversion, land use change, or extreme ground-water pumpage (Slack and Landwehr, 1992). This HydroClimatic Data Network (HCDN) includes data from over 1500 river flow gaging stations across the United States. For this study, we used all the HCDN stations in New England with daily flows relatively free of anthropogenic influences and having at least 50 continuous years of record up to water year 2000 (October 1, 1999 to September 30, 2000). The data 
Table 1

Attained significance level ( $p$-value) for Mann-Kendall trend test results

\begin{tabular}{|c|c|c|c|c|c|c|c|c|c|c|}
\hline \multirow{2}{*}{$\begin{array}{l}\text { USGS } \\
\text { Station } \\
\text { number }\end{array}$} & \multirow{2}{*}{$\begin{array}{l}\text { River } \\
\text { name and } \\
\text { state }\end{array}$} & \multirow{2}{*}{$\begin{array}{l}\begin{array}{l}\text { Period of } \\
\text { record }\end{array} \\
1951-2000\end{array}$} & \multicolumn{2}{|c|}{$\begin{array}{l}\text { Fall center- } \\
\text { volume date }\end{array}$} & \multicolumn{2}{|c|}{$\begin{array}{l}\text { Fall peak } \\
\text { flow date }\end{array}$} & \multicolumn{2}{|c|}{$\begin{array}{l}\text { Winter/spring } \\
\text { center- } \\
\text { volume date }\end{array}$} & \multicolumn{2}{|c|}{$\begin{array}{l}\text { Winter/spring } \\
\text { peak flow } \\
\text { date }\end{array}$} \\
\hline & & & 0.62 & - & 0.93 & + & 0.0087 & - & 0.24 & - \\
\hline 01010500 & St John, ME & $1947-2000$ & 0.33 & - & 0.88 & + & 0.0081 & - & 0.10 & - \\
\hline 01013500 & Fish, ME & $1904-08,1930-2000$ & 0.73 & + & 0.60 & + & 0.0020 & - & 0.16 & - \\
\hline 01014000 & St John, ME & $1927-2000$ & 1.0 & & 0.49 & + & 0.0056 & - & 0.085 & - \\
\hline 01022500 & Narraguagus, ME & $1949-2000$ & 0.26 & - & 0.16 & - & 0.49 & - & 0.38 & - \\
\hline 01030500 & Mattawamkeag, ME & $1935-2000$ & 0.84 & - & 0.36 & - & 0.0024 & - & 0.046 & - \\
\hline 01031500 & Piscataquis, ME & $1903-2000$ & 0.95 & - & 0.83 & - & 0.0016 & - & 0.0042 & - \\
\hline 01038000 & Sheepscot, ME & $1939-2000$ & 0.090 & - & 0.095 & - & 0.031 & - & 0.060 & - \\
\hline 01047000 & Carrabassett, ME & $1903-06,1926-2000$ & 0.91 & + & 0.38 & - & 0.0063 & - & $\mathbf{0 . 0 3 3}$ & - \\
\hline 01052500 & Diamond, NH & $1942-2000$ & 0.85 & + & 0.49 & + & 0.049 & - & 0.56 & - \\
\hline 01055000 & Swift, ME & $1930-2000$ & 0.55 & - & 0.82 & - & 0.011 & - & 0.0071 & - \\
\hline 01057000 & Little Androscoggin, ME & $1914-23,1932-2000$ & 0.65 & - & 0.18 & - & 0.065 & - & 0.34 & - \\
\hline 01060000 & Royal, ME & $1950-2000$ & 0.17 & - & 0.16 & - & 0.15 & - & 0.47 & - \\
\hline 01064500 & Saco, NH & $1904-09,1930-2000$ & 0.71 & + & 0.45 & + & 0.054 & - & 0.34 & - \\
\hline 01073000 & Oyster, NH & $1936-2000$ & 0.017 & - & 0.060 & - & 0.76 & - & 0.051 & + \\
\hline 01076500 & Pemigewasset, $\mathrm{NH}$ & $1904-2000$ & 0.80 & + & 0.39 & - & 0.29 & - & 0.26 & - \\
\hline 01078000 & Smith, NH & $1919-2000$ & 0.022 & - & 0.043 & - & 0.73 & - & 0.85 & + \\
\hline 01117500 & Pawcatuck, RI & $1942-2000$ & 0.75 & + & 0.55 & - & 0.57 & - & 0.73 & - \\
\hline 01118500 & Pawcatuck, RI & $1942-2000$ & 0.79 & + & 0.74 & - & 0.56 & - & 0.72 & + \\
\hline 01121000 & Mount Hope, CT & $1941-2000$ & 0.19 & - & 0.012 & - & 0.24 & - & 0.74 & - \\
\hline 01127500 & Yantic, CT & $1931-2000$ & 0.50 & - & 0.30 & - & 0.11 & - & 0.99 & - \\
\hline 01134500 & Moose, VT & $1948-2000$ & 0.097 & - & 0.93 & + & 0.12 & - & 0.25 & - \\
\hline 01137500 & Ammonoosuc, $\mathrm{NH}$ & $1940-2000$ & 0.88 & - & 0.77 & - & 0.046 & - & 0.061 & - \\
\hline 01144000 & White, VT & $1916-27,1929-2000$ & 0.77 & - & 0.14 & - & 0.68 & - & 0.94 & + \\
\hline 01169000 & North, MA & $1950-2000$ & 0.11 & - & 0.77 & - & 0.078 & - & 0.26 & - \\
\hline 01188000 & Burlington, CT & $1932-2000$ & 0.19 & - & 0.050 & - & 0.25 & - & 0.26 & - \\
\hline 01204000 & Pomperaug, CT & $1933-2000$ & 0.31 & - & 0.021 & - & 0.95 & - & 0.53 & - \\
\hline
\end{tabular}

Numbers in bold indicate $p \leq 0.1$. Positive or negative signs after the numbers indicate the sign of Kendall's Tau for each Mann-Kendall test. A negative sign indicates earlier dates over time.

were obtained from the USGS National Water Information System (US Geological Survey, 1998). Twenty-seven sites in New England met the criteria of this study (Fig. 1, Table 1). The sites had periods of record ranging from 50 to 98 years with an average of 68 years.

The annual winter/spring and fall peak flows used in this paper were the largest daily mean flows from January 1 to May 31, and October 1 to December 31, respectively. The seasonal volume was computed by summing the daily volumes from the start to the end of each season. The seasonal center of volume date was computed as the date, from the start of the season, by which half or more of the seasonal volume flowed by a gaging station. Julian date was used for all annual timing analyses in this paper. A small bias is introduced by using a calendar date rather than using timing relative to the vernal equinox. The maximum bias is 0.8 days (Sagarin, 2001), for sites with data from 1900 to 2000 .

Air temperature and precipitation time series were obtained from the US Historical Climatology Network (USHCN) data set that was developed and is maintained at the National Climatic Data Center (Karl et al., 1990). The data have been subjected to quality control and homogeneity testing. Temperature data have been adjusted for bias originating from changes in observation time (Karl et al., 1986), instrumentation (Quayle et al., 1991), station location and other station changes (Karl and Williams, 1987), and urban heat-island effects (Karl et al., 1988). Precipitation data have been adjusted for bias originating from 


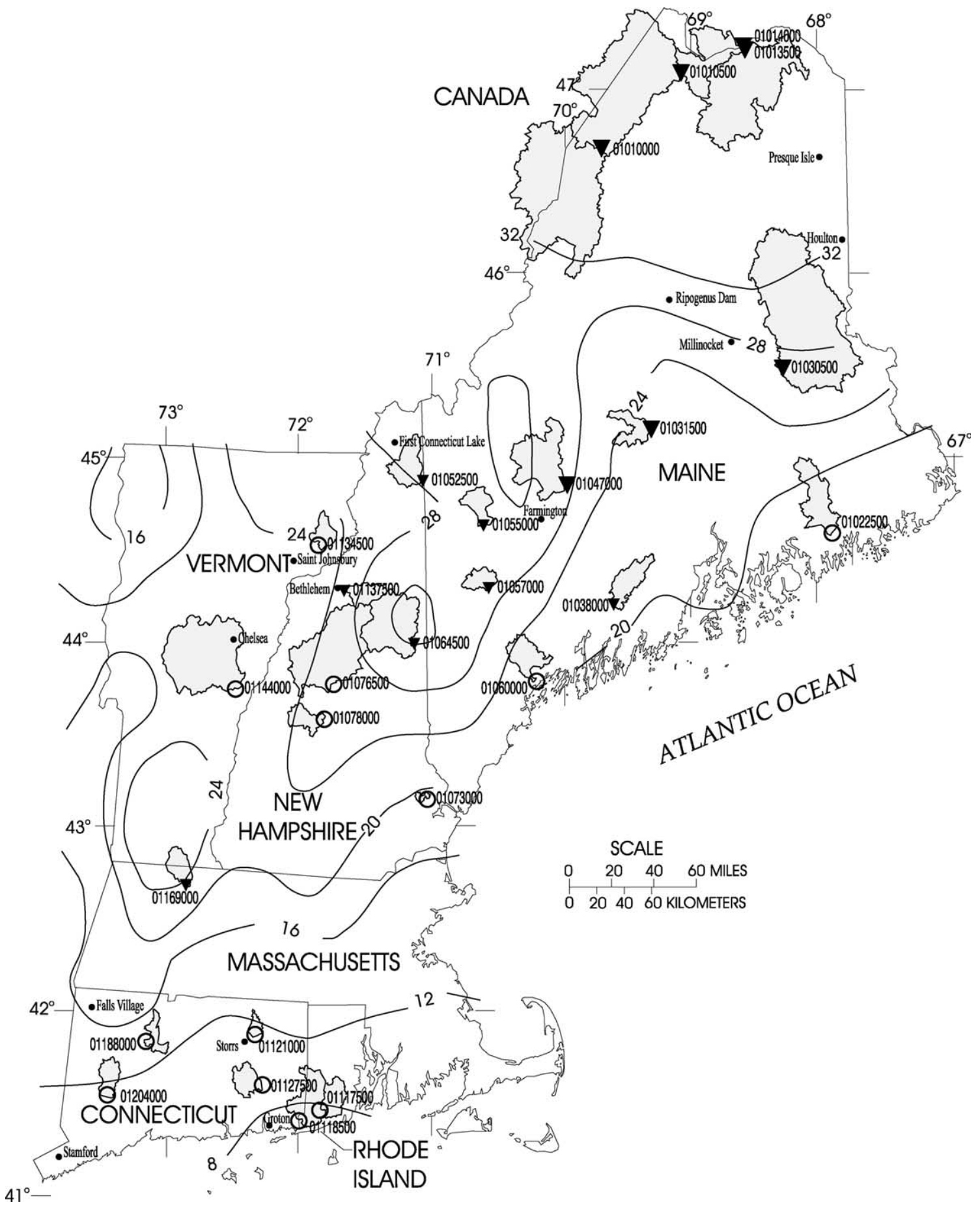

Fig. 1. USGS river gaging stations and temporal trend test results for winter/spring center of volume dates, USHCN observation stations, and contours of median seasonal maximum snow depth in inches from Cember and Wilks (1993) in New England. Drainage basins for each river gaging station are shaded in gray. Large triangles represent significant trends $(p<0.01)$ at gaging stations, small triangles represent significant trends $(p<0.1)$, and open circles represent insignificant trends $(p>0.1)$. USHCN stations are represented by a solid circle. 
changes in station location and other station changes (Karl and Williams, 1987).

\subsection{Methods of analysis}

Pearson's $r$ was used as the measure of correlation in this paper. Temporal trends in the annual timing of river volumes and the timing of peak flows were evaluated using the non-parametric Mann-Kendall test (Helsel and Hirsch, 1992) because changes over time did not appear to be linear. The data were smoothed for graphical presentation and serial correlation testing by use of locally weighted regression (LOESS) (Cleveland and Devlin, 1988) with locally linear fitting, a robustness feature, and a weighting function of 45 years. There must be no serial correlation for the Mann-Kendall test $p$-values to be correct. Serial correlations were analyzed by computing the Durbin-Watson statistic on the residuals of the LOESS smooths for each river that had a significant temporal trend $(p<0.1)$ in any category. The Durbin-Watson statistic is a standard statistic for evaluating serial correlation and is very closely related to a serial correlation coefficient (Helsel and Hirsch, 1992). None of the rivers considered here had significant positive serial correlation $(p<0.1)$.

\section{Results and discussion}

\subsection{Temporal trends}

Some river gaging stations in New England had significantly earlier $(p<0.1)$ fall center of volume dates and (or) fall peak flow dates over their periods of record (Table 1). Four of the 27 river gaging stations had significantly earlier fall center of volume dates and six of the 27 had significantly earlier fall peak flow dates. The river gaging stations with negative trends (trends toward earlier dates) that were not statistically significant $(p>$ 0.1 ) outnumbered the river gaging stations with positive trends that were not significant by about two to one. Three of the four river gaging stations with significantly earlier fall center of volume dates were located in New Hampshire or eastern Vermont. Three of the six river gaging stations with significantly earlier peak flows were located in Connecticut and the other three were located in southern Maine and southern New Hampshire.

The WSCV date has become significantly earlier (six of 11 sites with $p<0.01$ and the remaining five of 11 sites with $p<0.1$ ) in areas of New England where snowmelt runoff has the most effect on spring river flows (Table 1, Fig. 1). These 11 river gaging stations have a majority of their drainage basins in the area that has a median seasonal maximum snow depth of more than 28 inches. The WSCV date has become significantly earlier $(p<0.1)$ at three of 16 sites in other parts of New England (southern New England, Vermont, and coastal Maine). All river gaging stations in New England with trends that were not significant $(p>0.1)$ had trends toward earlier WSCV dates. The winter/spring peak flow date has become earlier $(p<0.1)$ at eight of 27 river gaging stations in New England, mostly in areas of New England where snowmelt runoff has the most effect. One site in coastal New Hampshire had significantly later peak flow dates.

For rivers in northern and mountainous areas of Maine and New Hampshire, the WSCV date is a more sensitive indicator of temporal changes in flows than is the peak flow date (Table 1). This is the result of the greater variability of annual peak flows dates compared to the WSCV dates. Seasonal peaks can occur before or after the seasonal center of volume. An example of the greater variability of the peak flow dates, for the Piscataquis River in central Maine, is shown in Fig. 2. The general trends over time (LOESS smooths) for the center of volume date and the peak flow date, however, are similar. This similarity is true for most rivers in the northern and mountainous areas of Maine and New Hampshire. Rivers in the rest of New England do not show these similarities.

Zhang et al. (2001) generally found trends that were not significant for starting dates of the spring high-flow season (both earlier and later) from 1947 to 1996, in areas of Canada to the northwest and northeast of New England. This could indicate that the mechanisms controlling the timing of Canadian flows did not change in the same way as New England mechanisms, that the Canadian measure of timing is not as sensitive as the WSCV date, or 


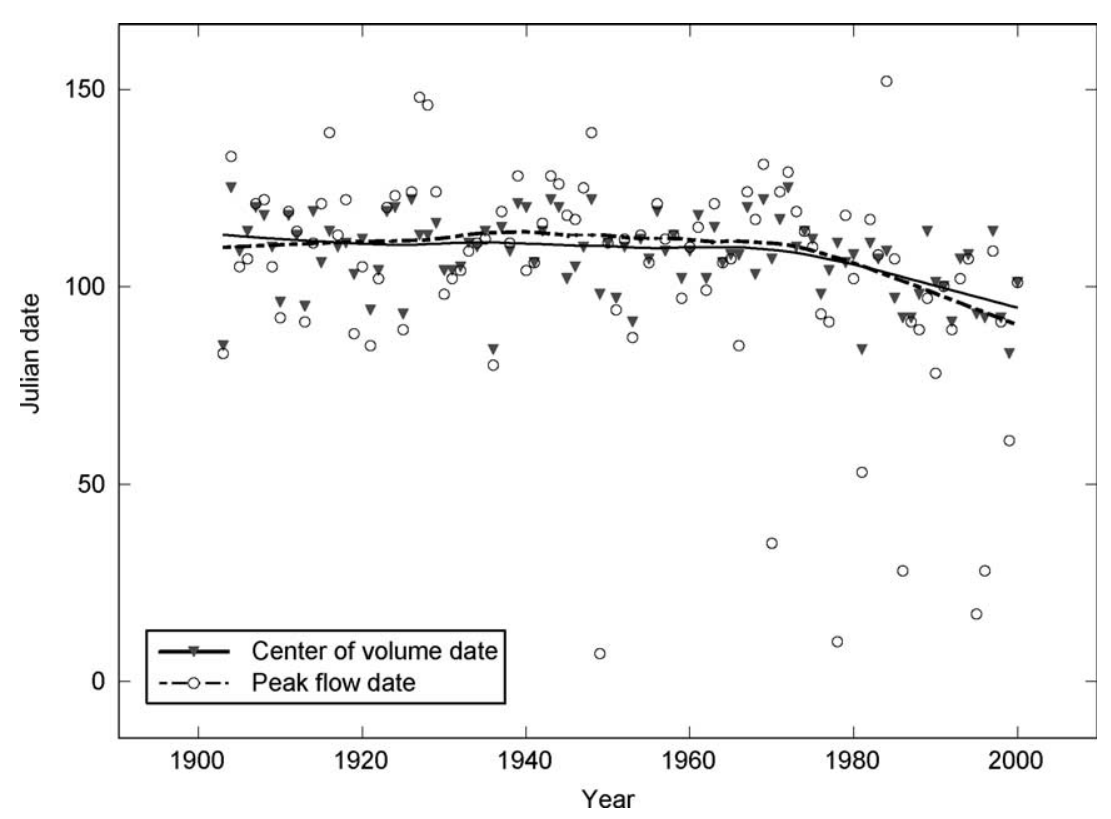

Fig. 2. Annual winter/spring center of volume dates and peak flow dates for the Piscataquis River in central Maine with LOESS smooths.

that the additional years of river flow from 1997 to 2000 used in this study strengthen the trend test results.

LOESS smooths of the WSCV dates over time for the 13 longest-record river gages in New England used in this study are shown in Fig. 3. The LOESS smooths for the three sites in Table 1 with less than 7 years of data in the first decade of the 1900's were truncated to when the records were restarted 2-3 decades later. Most of the change in WSCV dates, in rivers with significant trends toward earlier dates, occurred from the late 1960's to 2000. Changes over time in WSCV dates for southern New England were less consistent among rivers. Prior to the late 1960's, the typical WSCV date ranged from about March 20 (Julian date 79) in Connecticut to about May 2 (Julian date 122) in northern Maine. Since the late 1960's, the average date, based on the LOESS smooths, has become earlier by 1-2 weeks in northern and mountainous areas of New England.

The change in WSCV dates over time probably is related to the amount and timing of spring snowmelt. Rivers with a greater ratio of snowmelt to total winter/spring flow generally showed more highly significant trends toward earlier WSCV dates. All of the rivers in this study whose drainage basins (or a majority of their drainage basins) have a median seasonal maximum snow depth of greater than 28 inches had significant $(p<0.1)$ trends toward earlier WSCV dates (Fig. 1). All rivers whose basins have snow depths of $<20$ in. did not have significant trends.

Because the rivers in this study did not have a consistent period of record (Table 1), the temporal trends in WSCV dates for all rivers were recalculated using flows from 1951 to 2000 . The significance level of three river gaging stations in northern Maine (01010500, 01013500, 01030500) fell from highly significant $(p<0.01)$ to significant $(p<0.1)$ whereas one river in western Maine (01055000) rose from significant to highly significant. Two rivers in central New Hampshire (01076500, 01078000), one river in northern Vermont (01134500), and one river in Connecticut (01188000) rose from not significant $(p>0.1)$ to significant, and one river in coastal Maine (01038000) fell from significant to not significant. All other rivers remained in the same significance category. Using a consistent time period for all rivers in New England, rivers with a greater ratio of snowmelt to total winter/spring flow still generally showed more highly significant trends toward earlier WSCV dates. 


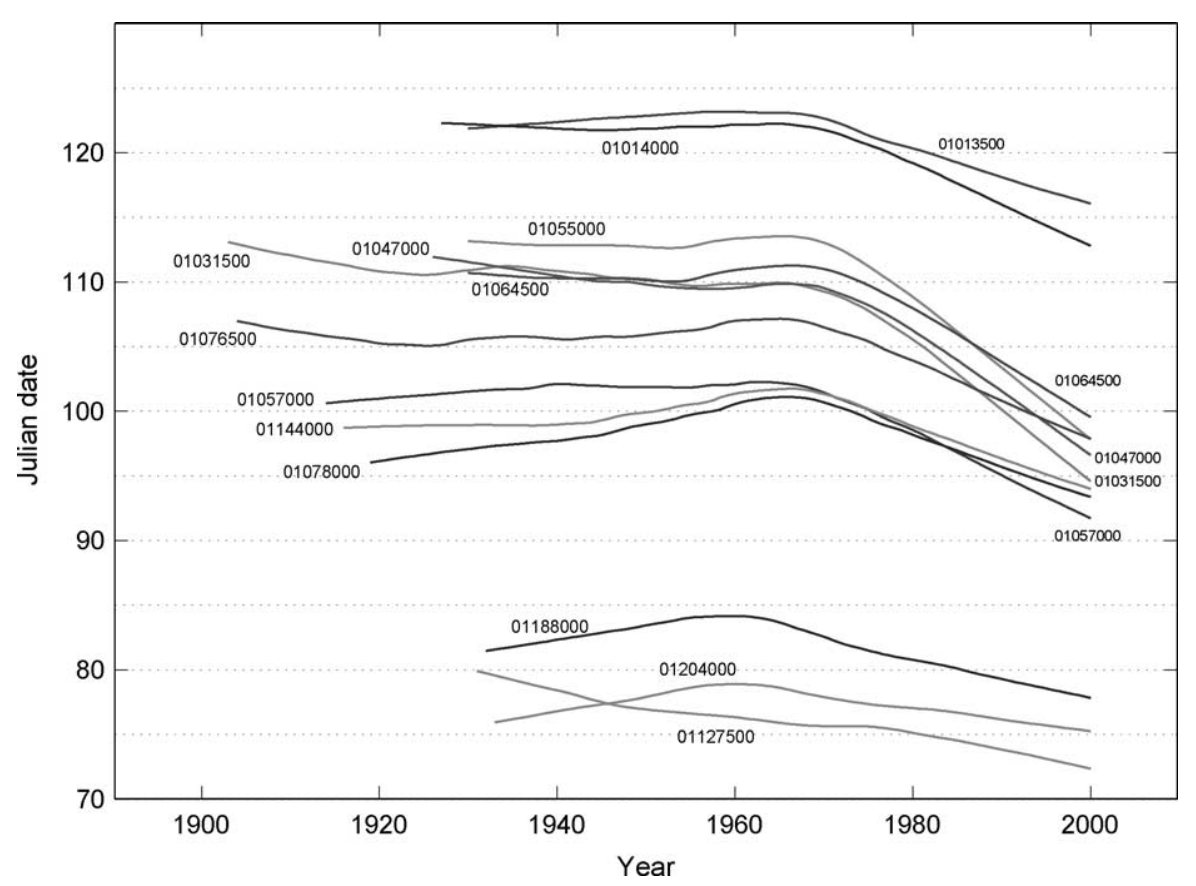

Fig. 3. LOESS smooths of winter/spring center of volume dates for the 13 longest-record rural, unregulated rivers in New England. Numbers are USGS gaging station numbers. River names are given in Table 1.

\subsection{Relation of flow volumes to temperature and precipitation}

If significantly earlier WSCV dates are caused by earlier snowmelt runoff, then annual WSCV dates should be related to late winter/early spring temperatures. WSCV dates were averaged for eight river gages in northern and mountainous areas of Maine and New Hampshire (01013500, 01014000, 01031500, 01047000, 01055000, 01057000, $01064500,01076500)$ and were correlated to average winter/spring temperatures from the seven USHCN stations closest to the river gages (Presque Isle, ME; Houlton, ME; Ripogenus Dam, ME; Millinocket, ME, Farmington, ME; First Connecticut Lake, NH; Bethlehem, NH; Fig. 1) for 1932-1999 (Table 2). Averages were used to avoid the potential problem of instrument or other biases at any one site, particularly at the USHCN sites which often have corrections applied over much of their period of record. The beginning year was chosen so there would be no missing values for the WSCV dates. Temperature data were compiled for all individual months from November through May and the following composites of months: March through April, February through April, January through April, and December through April. The highest correlation with the average WSCV dates was March through April temperatures $(r=-0.72)$. Both March and April had correlation coefficients near -0.6 . All remaining months had $r$ values of less than 0.35 . The aggregate month correlations decreased steadily as more months prior to March and April were aggregated.

The changes in average WSCV dates also might be related to changes in precipitation amounts. Average winter/spring total precipitation amounts from the same seven USHCN stations, for the same years and months used for the temperature correlations, were compared to the average WSCV dates (Table 2). The highest correlation with an individual month was with January $(r=-0.37)$. All other months had correlation coefficients of less than 0.20. Higher January precipitation is related to earlier WSCV dates. This may be the result of more precipitation falling in warmer Januarys. More rain in January would cause the WSCV date for that year to be earlier. For this hypothesis to be internally consistent, January precipitation and January temperature should be 
Table 2

Correlation coefficients, with attained significance levels ( $p$-values), for average winter/spring center of volume dates versus average temperatures and precipitation for northern and mountainous areas of Maine and New Hampshire

\begin{tabular}{llcc}
\hline Time period & Temperature & $p$-value & Precipitation \\
\hline November & +0.09 & 0.48 & +0.16 \\
December & -0.33 & 0.0053 & -0.08 \\
January & -0.04 & 0.71 & -0.37 \\
February & -0.18 & 0.14 & +0.08 \\
March & -0.60 & $<0.0001$ & -0.17 \\
April & -0.61 & $<0.0001$ & -0.05 \\
May & -0.24 & 0.052 & -0.04 \\
March to April & -0.72 & $<0.0001$ & -0.15 \\
February to April & -0.64 & $<0.0001$ & -0.09 \\
January to April & -0.57 & $<0.0001$ & -0.27 \\
December to April & -0.46 & 0.0001 & -0.12 \\
\hline
\end{tabular}

positively correlated which, in fact, they are $(r=0.25, p=0.036)$.

The highest WSCV correlation with aggregate months was with January through April precipitation $(r=-0.27)$. All other aggregate combinations had correlation coefficients of less than 0.15 . All of the precipitation correlations were much lower than the best temperature correlations, however, indicating that spring snowmelt runoff was more sensitive to changes in temperature than changes in precipitation amount.

\subsection{Consistency of results with other New England data series}

Other geophysical and biological changes in spring in New England are consistent with observations of earlier WSCV dates. The annual date of the last hard spring freeze (Cooter and Leduc, 1995) and lilac bloom dates at 4 stations (Schwartz and Reiter, 2000) became significantly earlier in New England from 1961 to 1990 and from 1959 to 1993, respectively. Much of the significant change toward earlier lake ice-out dates in New England since the 1800's occurred from 1968 to 2000 (Hodgkins et al., 2002). Lake ice-out dates became later from 1945 to 1968 . This feature is not as distinct in the WSCV dates. Lake ice-out dates and river WSCV dates were correlated with March through April air temperatures, both with a correlation coefficient of about 0.70 . March through
May air temperatures in New England increased from 1976 to 2000 (Intergovernmental Panel on Climate Change, 2001). The consistency in the direction of the changes in these diverse data series suggests the same common causal mechanism, temperature increases, as the cause of earlier springs in New England in the last 30 years.

\section{References}

Aguado, E., Cayan, D., Riddle, L., Roos, M., 1992. Climatic fluctuations and the timing of West Coast streamflow. J. Clim. 5, $1468-1483$.

Burn, D.H., 1994. Hydrologic effects of climatic change in westcentral Canada. J. Hydrol. 160, 53-70.

Burn, D.H., Hag Elnur, M.A., 2002. Detection of hydrologic trends and variability. J. Hydrol. 255, 107-122.

Cayan, D.R., Kammerdiener, S.A., Dettinger, M.D., Caprio, J.M., Peterson, D.H., 2001. Changes in the onset of spring in the western United States. Bull. Am. Meteorol. Soc. 82, 399-415.

Cember, R.P., Wilks, D.S., 1993. Climatological Atlas of Snowfall and Snow Depth for the Northeastern United States and Southeastern Canada, Northeast Regional Climate Center Publication No. RR 93-1, Ithaca, New York.

Chiew, F.H.S., McMahon, T.A., 1996. Trends in historical streamflow records, Regional Hydrological Response to Climate Change, Kluwer, Dordrecht, pp. 63-68.

Cleveland, W.S., Devlin, S.J., 1988. Locally-weighted regression: an approach to regression analysis by local fitting. J. Am. Stat. Assoc. 83, 596-610.

Cooter, E.J., Leduc, S.K., 1995. Recent frost date trends in the north-eastern USA. Int. J. Climatol. 15, 65-75.

Court, A., 1962. Measures of streamflow timing. J. Geophys. Res. $67,4335-4339$. 
Dettinger, M.D., Cayan, D.R., 1995. Large-scale atmospheric forcing of recent trends toward early snowmelt runoff in California. J. Clim. 8, 606-623.

Dettinger, M.D., Diaz, H.F., 2000. Global characteristics of stream flow seasonality and variability. J. Hydrometeorol. 1, 289-310.

Douglas, E.M., Vogel, R.M., Kroll, C.N., 2000. Trends in floods and low flows in the United States: impact of spatial correlation. J. Hydrol. 240, 90-105.

Helsel, D.R., Hirsch, R.M., 1992. Statistical Methods in Water Resources, Elsevier, Amsterdam.

Hodgkins, G.A., James, I.C. II, Huntington, T.G., 2002. Historical changes in lake ice-out dates as indicators of climate change in New England, 1850-2000. Int. J. Climatol 22, 1819-1827.

Hyvarinen, V., Leppajarvi, R., 1989. Long-term trends in river flow in Finland. Conf. Clim. Water, Helsinki, Finland, 11-15 September, 1989 1, 450-461.

Intergovernmental Panel on Climate Change, 2001. Climate Change 2001, The Scientific Basis, Cambridge University Press, Cambridge.

Karl, T.R., Williams, C.N., 1987. An approach to adjusting climatological time series for discontinuous inhomogeneities. J. Clim. Appl. Meteorol. 26, 1744-1763.

Karl, T.R., Williams, C.N. Jr, Young, P.J., 1986. A model to estimate the time of observation bias associated with monthly mean maximum, minimum, and mean temperatures for the United States. J. Clim. Appl. Meteorol. 25, 145-160.

Karl, T.R., Diaz, H., Kukla, G., 1988. Urbanization: its detection in the climate record. J. Clim. 1, 1099-1123.

Karl, T.R., Williams, C.N. Jr, Quinlan, F.T., Boden, T.A., 1990. United States historical climatology network (HCN) serial temperature and precipitation data, Publication No. 3404,
Carbon Dioxide Information and Analysis Center, Oak Ridge National Laboratory, Oak Ridge, TN.

Lettenmaier, D.P., Wood, E.F., Wallis, J.R., 1994. Hydroclimatological trends in the continental United States, 194888. J. Clim. 7, 586-607.

Lins, H.F., Michaels, P.J., 1994. Increasing US streamflow linked to greenhouse forcing. Eos Trans. AGU 75, 281, see also pp. 284-285.

Lins, H.F., Slack, J.R., 1999. Streamflow trends in the United States. Geophys. Res. Lett. 26, 227-230.

McCabe, G.J., Wolock, D.M., 2002. A step increase in streamflow in the conterminous United States. Geophys. Res. Lett. 29, (24) 2185, doi: 10.1029/20026L015999.

Quayle, R.G., Easterling, D.R., Karl, T.R., Hughes, P.Y., 1991. Effects of recent thermometer changes in the cooperative station network. Bull. Am. Meteorol. Soc. 72, 1718-1723.

Sagarin, R., 2001. False estimates of the advance of spring. Nature 414,600 .

Schwartz, M.D., Reiter, B.E., 2000. Changes in North American spring. Int. J. Climatol. 20, 929-932.

Slack, J.R., Landwehr, J.M., 1992. Hydro-climatic data network (HCDN): A US Geological Survey streamflow data set for the United States for the study of climate variations, 1874-1988, US Geological Survey Open-File Report 92-129, Reston, Virginia.

US Geological Survey, 1998. National Water Information System (NWIS), US Geological Survey Fact Sheet FS-027-98, Reston, Virginia.

Zhang, X., Harvey, K.D., Hogg, W.D., Yuzyk, T.R., 2001. Trends in Canadian streamflow. Water Resour. Res. 37, 987-998. 